\title{
Identifying Conceptual Skills of Future Battle Commanders
}

\author{
Shawn A. Noble \\ Kansas State University \\ Consortium Research Fellows Program \\ Jon J. Fallesen \\ U.S. Army Research Institute
}

Fort Leavenworth Research Unit

Stanley M. Halpin, Chief

U.S. Army Research Institute for the Behavioral and Social Sciences 5001 Elsenhower Avenue, Alexandria, Virginia 22333-5600

March 2000 